\title{
EVALUASI IMPLEMENTASI KURIKULUM 2013 DI MADRASAH
}

\section{EVALUATION OF THE IMPLEMENTATION OF 2013 CURRICULUM IN MADRASAH}

\author{
Sumarni \\ Puslitbang Pendidikan Agama dan Keagamaan \\ Badan Litbang dan Diklat Kementerian Agama \\ Jl. MH. Thamrin N0. 6 Jakarta Pusat \\ E-Mail: marni_ch@yahoo.com.au
}

Naskah diterima 9 Oktober 2017, direvisi 6 November 2017, disetujui 15 November 2017

\begin{abstract}
The Ministry of Religion in 2014 conducted a pilot implementation of the 2013 curriculum for the subjects of Islamic Education and Arabic. This study focuses on the policy of implementation and implementation of Curriculum 2013 in Madrasah Aliyah (MA) of West Java. This study uses quantitative approach. The research subjects were madrasah head, teacher, learner, supervisor, and madrasah committee. The instruments used were questionnaires, interview guides, and documentation. The data was analyzed using quantitative descriptive technique. The results show that most respondents understand the purpose of the implemented curriculum 2013 and the scientific approach used. In the implementation of the 2013 curriculum, most of the respondents also stated that PAI teachers already have the ability to learn in the 2013 curriculum. The 2013 Curriculum Implementation also has a positive impact for students, teachers and Madrasah Aliyah. Nevertheless, there are still some problems that arise related to infrastructure, teacher training, teacher and student handbooks, and the absence of monitoring and evaluation monitoring from the government towards the implementation of Curriculum 2013.
\end{abstract}

Keywords: Evaluation, Implementation, Curriculum 2013, Madrasah

\begin{abstract}
Abstrak
Kementerian Agama pada tahun 2014 melakukan uji coba implementasi kurikulumm 2013 untuk mata pelajaran Pendidikan Agama Islam dan Bahasa Arab. Studi ini memfokuskan pada kebijakan implementasi dan penelahaan terhadap implementasi Kurikulum 2013 di Madrasah Aliyah (MA) wilayah Jawa Barat. Penelitian ini menggunakan pendekatan kuantitatif. Subjek penelitian adalah kepala madrasah, guru, peserta didik, pengawas, dan komite madrasah. Instrumen yang digunakan yaitu lembar angket, pedoman wawancara, dan dokumentasi. Analisis data menggunakan teknik deskriptif kuantitatif. Hasil penelitian menunjukkan bahwa sebagian besar responden memahami tujuan dari diimplementasikan kurikulum 2013 dan pendekatan saintifik yang digunakan. Dalam implementasi kurikulum 2013, sebagian besar responden juga menyatakan yakin bahwa para guru PAI sudah memiliki kemampuan dalam pembelajaran dengan kurikulum 2013. Implementasi Kurikulum 2013 juga memiliki dampak positif baik bagi peserta didik, guru, dan Kepala MA. Namun demikian masih ada beberapa permasalahan yang muncul terkait dengan sarana prasarana, pelatihan guru, buku pegangan untuk guru dan siswa, serta tidak adanya evaluasi dan monitoring monitoring dari pemerintah terhadap implemntasi Kurikulum 2013.
\end{abstract}

Kata kunci : Evaluasi, Implementasi, Kurikulum 2013, Madrasah 


\section{PENDAHULUAN}

Kurikulum 2013 digulirkan sebagai langkah pengembangan kurikulum berbasis kompentensi (KBK) yang dirilis pada tahun 2004 dan kurikulum tahun 2006. Pemerintah melalui Kementerian Pendidikan dan Kebudayaan telah mulai mengimplementasikan kurikulum 2013 Tahun Pelajaran 2013/2014 untuk sebagian sekolah umum. Namun Kementerian Agama belum melaksanakan ujicoba pelaksanaan kurikulum 2013 di madrasah. Keputusan yang berbeda antara Kemenag dan Kemendikbud didasarkan pada langkahlangkah ideal suatu implementasi kurikulum dan melihat kesiapan madrasah sebagai pelaksana kurikulum.

Implementasi kurikulum 2013 di madrasah memiliki problem yang hampir sama dengan sekolah pada umumnya. Secara konsep dan formula implementasi kurikulum 2013 di madrasah didasari atas kebijakan tersendiri yaitu kebijakan yang dirumuskan oleh Kementerian Agama, dalam hal ini Direktorat Jenderal Pendidikan Islam. Maka, secara sederhana dapat dikatakan bahwa implementasi kurikulum 2013 di Kementerian Agama mulai dari penyiapan konsep, perangkat lunak, dan perangkat keras pada hakekatnya berada di Ditjen Pendidikan Islam tersebut.

Pada awal implementasi kurikulum 2013, Puslitbang Pendidikan Agama dan Keagamaan, Badan Litbang dan Diklat melakukan kajian dan serangkaian workshop dalam rangka menjaring informasi secara ilmiah terhadap kondisi riil madrasah untuk akan (dan sedang) mengimplementasikan kurikulum 2013. Salah satu kajian penting merekomendasikan bahwa implementasi kurikulum 2013 di madrasah seyogianya ditunda hingga persiapan selesai. Rekomendasi ini dikuatkan dengan data lapangan yang dijaring melalui kegiatan workshop di tiga titik yaitu Sumatera Selatan (melibatkan Propinsi Lampung, Jambi dan Sumsel sendiri), Banyuwangi Jawa Timur (melibatkan tiga kabupaten/kota yaitu Banyuwangi, Bondowoso, Jember), dan di Kalimantan Selatan (melibatkan dua propinsi yaitu Kalimantan Selatan dan Kalimantan Tengah). Data lapangan yang terjaring melalui tiga workshop tersebut menunjukkan bahwa madrasah belum siap mengimpelementasikan kurikulum 2013. ${ }^{1}$ Dalam workshop yang dilakukan di tiga titik ini, Puslitbang Pendidikan Agama dan Keagamaan melakukan survei yang ditujukan kepada peserta workshop dengan menggunakan instrumen yang didesain khusus untuk mengetahui kesiapan guru dalam implementasi kurikulum 2013. Halhal yang dijaring antara lain : pengetahuan tentang kurikulum 2013, pemahaman, kelengkapan dokumen, kompetensi guru tentang Kurikulum 2013, keberadaan guru inti,jumlahguruyangikutdiklat,pemahaman buku pedoman guru, pemahaman buku pedoman siswa, pemahaman silabus, pemahaman RPP, pemahaman model penilaian dan pemahaman KI/KD. Dari semua unsur yang dijaring, rata-rata masih menunjukkan prosentase yang rendah, terutama yang terkait dengan kompetensi dan pengetahuan guru tentang kurikulum 2013.

${ }^{1}$ Dalam workshop yang dilakukan di tiga titikini, dilaksanakan di awal tahun 2013 yang dimaksudkan untuk menjaring data sebagai bahan Ditjen Pendidikan Islam dalam merancang implementasi Kurikulum 2013. 
Akan tetapi, kebijakan pemerintah terhadap impelementasi kurikulum 2013 ini tidak bisa dihindari, bahwa sekolah dan madrasah harus mengimplementasikan kurikulum 2013, meskipun tidak secara total. Dasar implementasi Kurikulum 2013 di madrasah adalah adanya Keputusan Menteri Agama Republik Indonesia Nomor 207 Tahun 2014 tentang Kurikulum Madrasah. Berdasarkan PMA tersebut, madrasah pada semua jenjang menggunakan Kurikulum Tingkat Satuan Pendidikan (KTSP) 2006 untuk mata pelajaran umum, dan menggunakan Kurikulum 2013 untuk mata pelajaran Pendidikan Agama Islam dan Bahasa Arab. Namun demikian, pada tahun awal implementasi, masih diberlakukan piloting yang ditetapkan berdasarkan Surat Keputusan Direktur Jenderal Pendidikan Islam.

Berdasarkan surat Keputusan Direktur Jenderal Pendidikan Islam Nomor 481 Tahun 2015 tentang Penetapan Madrasah Pendampingan Kurikulum 2013, untuk wilayah Jawa Barat, madrasah yang melaksanakan Kurikulum 2013 ada 34 madrasah, terdiri dari 8 Madrasah Ibtidaiyah, 18 Madrasah Tsanawiyah, dan 8 Madrasah Aliyah yang melaksanakan kurikulum 2013.

Studi ini memfokuskan pada kebijakan implementasi Kurikulum 2013 di wilayah Jawa Barat dan penelahaan terhadap implementasi Kurikulum 2013. Penelitian ini dilakukan di Madrasah Aliyah program pendampingan implementasi Kurikulum 2013 tahun ajaran 2014-2015 khususnya pada 8 MA di lingkup Kantor Wilayah Kementerian Agama Provinsi Jawa Barat, yang berkaitan pemahaman terhadap Kurikulum 2013, proses pembelajaran, dampak penerapan K-13 terhadap peserta didik, guru, dan Kepala Madrasah, penilaian terhadap buku teks siswa dan buku pegangan guru, dan penilaian terhadap pelatihan K-13 pada aspek materinya, metode dan alokasi waktunya, cara penyampaian materi oleh pelatih, dan sarana prasarana pelatihan. Selain itu, penelitian ini juga menggali faktor pendukung implementasi kurikulum 2013 di madrasah dan juga permasalahan yang muncul dalam implementas kurikulum 2013 tersebut.

Tujuan penelitian ini untuk mengetahui kebijakan implementasi Kurikulum 2013 di kantor wilayah Kemenag Jawa Barat dan bagaimana implementasi Kurikulum 2013 pada MA program Pendampingan implementasi Kurikulum 2013 tahun ajaran 2014-2015 serta apa saja dampak implementasi kurikulum 2013 bagi warga madrasah. Penelitian ini juga bertujuan untuk mengetahui faktor apa saja yang mendukung dalam implementasi kurikulum di MA dan permasalahan yang muncul dalam implementasi kurikulum 2013 tersebut. Hasil penelitian ini diharapkan dapat digunakan sebagai bahan masukan kepada Ditjen Pendidikan Islam Kementerian Agama, khususnya Direktorat Pendidikan Madrasah dalam mengambil kebijakan dalam pengembangan Kurikulum 2013 di madrasah. Bagi madrasah, khususnya Madrasah Aliyah hasil penelitian ini bisa dijadikan untuk referensi dalam pengembangan dan implementasi kurikulum 2013 di madrasah masing-masing.

\section{Kerangka Konseptual}

Evaluasi adalah kegiatan untuk mengumpulkan informasi tentang bekerjanya sesuatu, yang selanjutnya 
informasi tersebut digunakan untuk menentukan alternatif yang tepat dalam mengambil keputusan. Fungsi utama evaluasi dalam hal ini adalah menyediakan informasi-informasiyangbergunabagipihak decision maker untuk menentukan kebijakan yang akan diambil berdasarkan evaluasi yang telah dilakukan. ${ }^{2}$ Evaluasi dapat juga diartikan sebagai "proses menilai sesuatu berdasarkan kriteria atau tujuan yang telah ditetapkan yang selanjutnya diikuti dengan pengambilan keputusan atas obyek yang dievaluasi". ${ }^{3}$ Dari pengertian-pengertian tersebut, dapat disimpulkan bahwa evaluasi merupakan sebuah proses yang dilakukan oleh seseorang untuk melihat sejauh mana keberhasilan sebuah program yang sudah diimplementasikan. Keberhasilan program itu sendiri dapat dilihat dari dampak atau hasil yang dicapai oleh program tersebut.

Implementasi adalah suatu tindakan atau pelaksanaan dari sebuah rencana yang sudah disusun secara matang dan terperinci. Menurut Oxford Advance Learner's Dictionary yang dikutip dalam Mulyasa, implementasi adalah penerapan suatu yang memberikan efek atau dampak. ${ }^{4}$ Lebih lanjut disebutkan implementasi adalah proses penerapan ide, konsep, kebijakan atau inovasi dalam suatu tindakan praktis sehingga memberikan dampak baik berupa perubahan pengetahuan, keterampilan, ataupun nilai dan sikap.

\footnotetext{
${ }^{2}$ Arikunto Suharsimi. 2004. Dasar-Dasar Evaluasi Pendidikan. Jakarta : Bumi Aksara, h 1

${ }^{3}$ Djaali dan Puji. 2008. Pengukuran Dalam Bidang Pendidikan. Jakarta : Grasindo, h 1

${ }^{4}$ Mulyasa, 2008. Implementasi Kurikulum Tingkat Satuan Pendidikan, Kemandirian Guru dan Kepala Sekolah. Jakarta : Bumi Aksara, h 178
}

Miller and Seller ${ }^{5}$ mengidentifikasi tiga makna implementasi yang umum dipahami. Pertama, implementasi adalah sebuah proses dimana guru menggunakan kurikulum baru disaat mereka mengajar. Kedua, implementasi adalah sebuah proses interaksi antar pembuat kurikulum dan guru (jika kurikulum tidak dibuat sendiri oleh guru). Dalam interaksi ini terjadi dialog antara pembuat kurikulum dan guru sebagai pelaksana kurikulum di lapangan. Keduanya memastikan bagaimana kurikulum yang telah direncanakan dapat diterapkan secara tepat dengan mempertimbangkan keadaan setempat. Ketiga, implementasi dianggap sebagai bagian tersendiri dari siklus kurikulum yang perlu direncanakan dan diorganisasikan secara khusus.

Menurut Nurdin Usman ${ }^{6}$, implementasi adalah bermuara pada aktivitas, aksi, tindakan, atau adanya mekanisme suatu sistem. Pengertian implementasi yang dikemukakan di atas, dapat dikatakan bahwa implementasi adalah bukan sekedar aktivitas, tetapi suatu kegiatan yang terencana dan dilakukan secara sungguhsungguh berdasarkan acuan norma tertentu untuk mencapai tujuan kegiatan. Oleh karena itu implementasi tidak berdiri sendiri tetapi dipengaruhi oleh objek berikutnya.

Sementara itu, Guntur Setiawan ${ }^{7}$ mendefinisikan implementasi sebagai perluasan aktivitas yang saling

${ }^{5}$ Miller, J.P. and Seller, W. 1985. Curriculum : Perspektif and Practice. New York : Longman, h. 249

6 Usman Nurdin. 2002. Konteks Implementasi Berbasis Kurikulum. Jakarta : PT. Raja Grafindo Persada, h.70

7 Setiawan Guntur. 2004. Implementasi Dalam Birokrasi Pembangunan. Bandung : Remaja Rosdakarya, h. 39 
menyesuaikan proses interaksi antara tujuan dan tindakan untuk mencapainya serta memerlukan jaringan pelaksana, birokrasi yang efektif. Pengertian implementasi yang dikemukakan di atas, dapat dikatakan bahwa implementasi yaitu merupakan proses untuk melaksanakan ide, proses atau seperangkat aktivitas baru dengan harapan orang lain dapat menerima dan melakukan penyesuaian dalam tubuh birokrasi demi terciptanya suatu tujuan yang bisa tercapai dengan jaringan pelaksana yang bisa dipercaya. Sedangkan menurut Hanifah Harsono ${ }^{8}$ implementasi adalah suatu proses untuk melaksanakan kebijakan menjadi tindakan kebijakan dari politik ke dalam administrasi. Pengembangan kebijakan dalam rangka penyempurnaan suatu program.

Dari beberapa definisi diatas dapat disimpulkan bahwa yang dimaksud implementasi dalam penelitian ini adalah suatu interaksi antara mereka yang menciptakan program dengan mereka yang dibebankan untuk menyampaikan program dalam mencapai suatu tujuan tertentu.

Sementara itu, kurikulum berasal dari bahasa Yunani, yaitu dari kata curir artinya pelari, kata curere artinya tempat berpacu. Jadi Curriculum diartikan jarak yang ditempuh oleh seorang pelari. Pada saat itu kurikulum diartikan sejumlah mata pelajaran yang harus ditempuh oleh siswa atau murid untuk mencapai suatu gelar atau ijazah. Rumusan kurikulum tersebut mengandung makna bahwa isi kurikulum tidak lain adalah sejumlah mata pelajaran

\footnotetext{
${ }^{8}$ Harsono Hanifah. 2002. Implementasi Kebijakan dan Politik. Bandung : PT. MutiaraSumber Widya, h. 67
}

(subjek matter) yang harus dikuasai siswa, agar siswa memperoleh ijazah itulah sebabnya kurikulum sering dipandang sebagai rencana pelajaran untuk siswa. ${ }^{9}$

Banyak definisi kurikulum yang dikemukakan para ahli. Definisi-definisi tersebut bersifat operasional dan sangat membantu proses pengembangan kurikulum tetapi pengertian makna kurikulum yang diajukan tidak lengkap. Definisi yang dikemukakan sering hanya berkenaan dengan salah satu dimensi kurikulum yaitu dimensi ide, dimensi dokumen, dimensi implementasi, dan dimensi hasil. ${ }^{10}$ Memang secara teknis kurikulum mencakup dimensi ide, dokumen tertulis, implementasi, dan hasil. Oleh karena itu definisi teknis yang dikemukakan seharusnya mencakup keempat dimensi tersebut bukan hanya mengenai salah satu dimensi kurikulum.

Secara konseptual, kurikulum adalah jawaban pendidikan terhadap kebutuhan dan tantangan masyarakat ${ }^{11}$. Definisi ini sering dilupakan orang padahal kurikulum dalam pengertian ini teramat penting karena definisi ini menggambarkan posisi pedagogis kurikulum dalam mengembangkan potensi peserta didik, dan landasan bagi pertanyaan utama yang harus dijawab ketika proses pengembangan suatu kurikulum akan dimulai. Oleh karena itu, pengertian ini sangat fundamental dan menggambarkan posisi sesungguhnya kurikulum dalam suatu proses pendidikan.

\footnotetext{
${ }^{9}$ Muzamiroh, M.L.2013. Kupas Tuntas Kurikulum 2013. Jakarta: Penata aksara, h. 15

10 Hasan, S.H.1999. Landasan Filosofi dan Teori Penyusunan Kurikulum., makalah disajikan dalam Seminar Kinerja PPPG-IPA, Bandung, 28 Juni .

11 Oliva P.F. 1997. Developing the Currulum 4th edition. Newyork : Longman, h. 60
} 
Atas dasar pemikiran tersebut, Klein ${ }^{12}$ menempatkan posisi kurikulum sebagai "the heart of education". Dengan posisi tersebut maka proses pengembangan kurikulum tidak boleh hanya terjebak pada pengertian kurikulum yang berkaitan dengan dimensi kurikulum semata dan bersifat praktis tetapi dimulai dengan jawaban yang diberikan pendidikan terhadap tantangan masyarakat bagi kehidupan manusia Indonesia di masa kini dan masa mendatang. Setelah jawaban tersebut diperoleh maka proses pengembangan kurikulum sebagai rencana tertulis baru dapat dimulai, dilanjutkan dengan pengembangan kurikulum sebagai proses pembelajaran, dan evaluasi hasil kurikulum.

Undang-Undang Nomor 20 Tahun 2003 Tentang Sistem Pendidikan Nasional dalam BAB 1 Pasal 1 Nomor 19 juga disebutkan bahwa Kurikulum adalah seperangkat rencana dan pengaturan mengenai tujuan, isi dan bahan pelajaran serta cara yang digunakan sebagai pedoman penyelenggaraan kegiatan pembelajaran untuk mencapai tujuan pendidikan tertentu. Definisi tersebut menegaskan bahwa kurikulum dipakai sebagai pedoman dalam menyelenggarakan pembelajaran bukan buku teks yang sebenarnya lebih berperan sebagai salah satu sumber pembelajaran.

Kurikulum $2013 \quad$ (K-13) adalah kurikulum yang berlaku dalam Sistem Pendidikan Indonesia. Kurikulum ini merupakan kurikulum tetap yang diterapkan oleh pemerintah untuk menggantikan Kurikulum-2006 (yang sering

12 Klein, M.F. 1989. Curriculum Reform in the Elementary School. Creating Your Own Agenda. New York and London: Teacher College Columbia University, hal.15 disebut sebagai Kurikulum Tingkat Satuan Pendidikan). Kurikulum 2013 masuk dalam masa percobaanya pada tahun 2013 dengan menjadikan beberapa sekolah menjadi sekolah rintisan.

Pada tahun ajaran 2013/2014, tepatnya sekitar pertengahan tahun 2013, Kurikulum 2013 diimpelementasikan secara terbatas pada sekolah perintis, yakni pada kelas I dan IV untuk tingkat Sekolah Dasar, kelas VII untuk SMP, dan kelas X untuk jenjang SMA/ SMK, sedangkan pada tahun 2014, Kurikulum 2013 sudah diterapkan di Kelas I, II, IV, dan V sedangkan untuk SMP Kelas VII dan VIII dan SMA Kelas X dan XI. Jumlah sekolah yang menjadi sekolah perintis adalah sebanyak 6.326 sekolah tersebar di seluruh provinsi di Indonesia.

Madrasah merupakan sebuah kata dalam bahasa Arab yang artinya sekolah. Dilihat dari segi bahasa, madrasah merupakan isim makãn (nama tempat) berasal dari kata darasa yang berarti tempat orang belajar. ${ }^{13}$ Madrasah adalah nama lain dari sekolah. ${ }^{14}$ Dengan demikian madrasah dipahami sebagai tempat atau lembaga pendidikan Islam. Dalam UU N0. 20 Tahun 2003 Madrasah Ibtidaiyah (MI) setara dengan Sekolah Dasar (SD), Madrasah Tsanawiyah (MTs) setara dengan Dalam penelitian ini sasarannya adalah Madrasah Aliyah (MA). Madrasah Aliyah ialah lembaga Pendidikan yang memberikan Pendidikan dan pengajaran tingkat menengah keatas dan menjadikan mata pelajaan agama Islam sebagai mata pelajaran dasar sekurang-

${ }^{13}$ Munawir, A. Warson. 1997. Kamus Al-Munawir. Surabaya: Pustaka Progresif, Cet XIV, hal 397

${ }^{14}$ Basri, Hasan dan Beni Ahmad Saebani. 2010. Ilmu Pendidikan Jilid II. Bandung : CV Pustaka Setia, Cet ke-1, hal 243 
kurangnya 30\% disamping mata pelajaran umum. Dalam perkembangannya, madrasah Aliyah memiliki jurusan-jurusan Pendidikan misalnya jurusan ilmu agama, jurusan Ilmu Pengetahuan Alam (IPA) dan jurusan Ilmu Pengetahuan Sosial (IPS). Kurikulum Madrasah Aliyah sama dengan kurikulum sekolah menengah atas, hanya saja pada MA terdapat porsi lebih banyak mengenai pendidikan agama Islam. Selain mengajarkan mata pelajaran sebagaimana sekolah umum, juga ditambah dengan pelajaranpelajaran seperti: Alquran dan Hadits, Aqidah dan Akhlaq, Fiqih, Sejarah Kebudayaan Islam, dan Bahasa Arab.

\section{Kerangka Berpikir}

Pengembangan kurikulum merupakan kegiatan sistematis dan terencana yang terdiri atas kegiatan pengembangan ide kurikulum, dokumen kurikulum, implementasi kurikulum, dan evaluasi kurikulum. Keempat dimensi kurikulum ini saling terkait dan merupakan satu kesatuan keseluruhan proses pengembangan. Sebagai bagian dari pengembangan kurikulum, evaluasi kurikulum merupakan kegiatan yang dilakukan sejak awal pengembangan ide kurikulum, pengembangan dokumen, implementasi, dan sampai kepada saat di mana hasil kurikulum sudah memiliki dampak di masyarakat. Evaluasi dalam proses pengembangan ide dan dokumen kurikulum dilakukan untuk mendapatkan masukan mengenai kesesuaian ide dan desain kurikulum untuk mengembangkan kualitas yang dirumuskan dalam Standar Kompetensi lulusan (SKL). Evaluasi terhadap implementasi dilakukan untuk memberikan masukan terhadap proses pelaksanaan kurikulum agar sesuai dengan apa yang telah dirancang dalam dokumen. Evaluasi terhadap hasil memberikan keputusan mengenai dampak kurikulum terhadap individu warga negara, masyarakat, dan bangsa. Secara singkat, evaluasi kurikulum dilakukan untuk menegakkan akuntabilitas kurikulum terhadap masyarakat dan bangsa.

Evaluasi terhadap ide dan dokumen kurikulum dilakukan terhadap upaya mencari informasi dan memberikan pertimbangan berkenaan dengan keajegan/konsistensi ide kurikulum untuk mengembangkan kualitas yang diharapkan, dan keajegan desain kurikulum dengan model dan prinsip pengembangan kurikulum. Evaluasi terhadap ide kurikulum menentukan apakah filosofi, teori, dan model yang akan dikembangkan telah mampu memenuhi fungsi kurikulum dalam mempersiapkan generasi muda bangsa untuk menjalani kehidupan sebagai seorang individu dan warga negara di masa yang akan datang sebagaimana ditetapkan dalam SKL.

Evaluasi kurikulum dilaksanakan dengan mengacu pada Pasal 57 ayat (2) Undang-Undang Nomor 20 Tahun 2003 Tentang Sistem Pendidikan Nasional yang menyatakan bahwa evaluasi dilakukan terhadap peserta didik, lembaga, dan program pendidikan. Disamping itu, evaluasi kurikulum juga perlu dilakukan pada lembaga pembina pendidikan seperti Kementerian Agama Pusat dan Wilayah. Dengan demikian, evaluasi kurikulum ini sesuai dengan Pasal 77Q ayat (1) Peraturan Pemerintah Nomor 32 Tahun 2013 tentang Perubahan Atas Peraturan Pemerintah Nomor 19 Tahun 2005 tentang Standar Nasional Pendidikan, dinyatakan bahwa 
evaluasi kurikulum merupakan upaya mengumpulkan dan mengolah informasi dalam rangka meningkatkan efektivitas pelaksanaan kurikulum pada tingkat nasional, daerah, dan satuan pendidikan.

\section{Studi Terdahulu}

Banyak penelitian sudah dilakukan terkait dengan kurikulum 2013 baik yang dilakukan di madrasah maupun pada sekolah umum. Penelitian yang dilakukan oleh Hamriah tentang "Implementasi Kurikulum 2013 Pada Madrasah Tsanawiyah Negeri (MTsN) Model Makasar" menunjukkan bahwa implementasi kurikulum 2013 di MTsN Model Makassar belum menunjukkan totalitas diantara faktor penghambatnya adalah kurangnya buku pegangan bagi guru mata pelajaran, sarana dan prasarana pembelajaran. Solusi madrasah terhadap implementasi kurikulum tersebut salah satunya adalah dengan melakukan pelatihan kurikulum 2013 bagi guru internal madrasah. ${ }^{15}$

Penelitian lain yang dilakukan oleh Siskandar tentang " Evaluasi Implementasi Kurikulum 2013 di Madrasah” menunjukkan bahwa ada beberapa faktor pendukung dan penghambat terhadap keberhasilan kurikulum 2013 di MA "Swasta" di Parung Bogor. Faktor-faktor yang menentukan keberhasilan kurikulum di madrasah adalah:

a) kelengkapan infrastruktur kurikulum,

b) kompetensi guru, c) kepemimpinan kepala sekolah, d) sarana dan prasarana pendidikan, e) iklim atau budaya sekolah,

${ }^{15}$ Hamriah . 2014. Implementasi Kurikulum 2013 pada Madrasah Tsanawiyah Negeri (MTsN) Model Makasar. Dalam jurnal "Al Qalam" Volume 20 Edisi Khusus Desember dan f) efektivitas monitoring dan evaluasi terhadap implementasi kurikulum. 2. Faktor yang menghambat pelaksanaan kurikulum di Madrasah Aliyah "Swasta" Parung Bogor angtara lain bersumber dari persepsi yang salah terhadap kurikulum yang baru, hambatan saat membuat perencanaan pembelajaran, hambatan saat pelaksanaan di kelas, hambatan dalam penilaian hasil belajar, hambatan dalam hal pemanfaat IT, hambatan dalam hal sarana an prasarana, dan hambatan dalam hal manajemen madrasah. ${ }^{16}$

Penelitian terkait dengan kurikulum 2013 dilakukan oleh Mulyani Mudis Taruna dari Balai Penelitian dan Pengembangan Agama Semarang yang berjudul "Kontribusi Madrasah Dalam Penguatan Kurikulum 2013" (Studi tentang Kesiapan Madrasah Dalam Pelaksanaan Kurikulum 2013 di Jawa Tengah). Penelitian ini bertujuan untuk mendeskripsikan kesiapan madrasah tsanawiyah (MTs) dalam implementasi Kurikulum 2013. Kesiapan tersebut meliputi kesiapan kepala MTs, kesiapan guru, serta faktor-faktor pendukung dan penghambat implementasi Kurikulum 2013 di MTs Negeri. Subyek penelitian ini adalah MTs Negeri di Jawa Tengah. Penelitian ini menggunakan metode kualitatif dengan hasil sebagai berikut : (1) secara umum kepala MTs Negeri dan guru mata pelajaran di madrasah telah mampu mengimplementasikan K-13, baik dari aspek fasilitas maupun dalam pelaksanaan pembelajaran di kelas; faktor pendukung dalam pelaksanaan kurikulum 2013 di MTs Negeri di antaranya

16 Siskandar 2016. Evaluasi Implementasi Kurikulum di Madrasah Aliyah. Pusat Kajian Bahasa dan Budaya Cendikia, volume 10 No. 2 Oktober, h. 117 
adanya workshop K-13 oleh sekolah maupun Kelompok Kerja Madrasah (KKM), sedangkan faktor penghambat dalam implementasi kurikulum 2013 adalah tidak adanya pendampingan pengawas madrasah dan belum ada buku pegangan guru dan peserta didik terutama pada mata pelajaran pendidikan agama. ${ }^{17}$

Andri Noviatmi juga melakukan penelitian yang diberi judul: Evaluasi Implementasi Kurikulum 2013 Kelas I \& IV SD di Kabupaten Magelang Tahun Pelajaran 2014/2015. Implementasi Kurikulum 2013 di Kabupaten Magelang masih menemui banyak kendala pada awal pelaksanaannya. Penelitian ini bertujuan untuk melakukan evaluasi terhadap implementasi Kurikulum 2013 kelas I \& IV SD di Kabupaten Magelang tahun pelajaran 2014/2015. Hasil penelitian menunjukkan bahwa (1) untuk mengimplementasi Kurikulum 2013 kondisi siswa berkategori cukup (54,9\%) dan kondisi guru berkategori cukup $(57,8 \%)$; (2) pemahaman guru terhadap Kurikulum 2013 berkategori baik (62,2\%); (3) dalam implementasi Kurikulum 2013, perencanaan pembelajaran berkategori sangat baik (85\%), pelaksanaan pembelajaran tematik integratif berbasis saintifik berkategori sangat baik (90\%), pelaksanaan penilaian autentik berkategori cukup (53,3\%), dan hasil penilaian autentik berkategori sangat baik (100\%). Hasil penelitian menunjukkan

17 Taruna, Mulyani Mudis. 2015. Kontribusi Madrasah Dalam Penguatan Kurikulum 2013 (Studi tentang Kesiapan Madrasah Dalam Pelaksanaan Kurikulum 2013 di Jawa Tengah. Dalam Analisa Journal of Social Science and Religion Volume 22 No. 01 June, h. 107 belum semua komponen pendidikan memenuhi standar. ${ }^{18}$

Tulisan ini secara khusus membahas hasil penelitian tentang pemahaman kurikulum 2013 tidak hanya pada guru dan kepala madrasah, tetapi juga peserta didik, pengawas, dan komite madrasah. Selain itu faktor-faktor penghambat dan pendukung dalam implementasi kurikulum 2013 juga menjadi salah satu pembahasan dalam tulisan ini. Tulisan ini juga membahas dampak implementasi kurikulum 2013 terhadap peserta didik, guru, kepala madrasah, dan pengawas.

\section{METODOLOGI PENELITIAN}

Pendekatan penelitian adalah pendekatan kuantitatif dengan mengandalkan analisa besaran prosentasi terhadap masing masing butir yang menjadi unit analisis. Kemudian, untuk melengkapi data sekaligus menjawab pertanyaan penelitian, evaluasi ini juga menggali data kualitatif yang dikumpulkan melalui wawancara, khususnya kepada pejabat pengambil kebijakan baik di Pusat (Direktorat Pendidikan Madrasah) maupun daerah (Kantor Wilayah Kementerian Agama) di propinsi yang menjadi sasaran penelitian.

Metode penelitian yang digunakan adalah metode deskriptif. Menurut Sukmadinata $^{19}$ penelitian deskriptif

18 Noviatmi, Andri. 2015. Evaluasi Implementasi Kurikulum 2013 Kelas I \& IV SD di Kabupaten Magelang Tahun Pelajaran 2014/2015. Thesis. Prodi Pendidikan Dasar Program Pascasarjana, Universitas Negeri Yogyakarta

${ }^{19}$ Sukmadinata, N.S. 2011. Metode Penelitian Pendidikan. Bandung: PT. Remaja Rosdakarya, Cet ke7, h. 73 
memiliki beberapa variasi, diantaranya bisa mendeskriptifkan sesuatu keadaan saja, tetapi bisa juga mendeskripsikan keadaan dalam tahapan-tahapan perkembangannya.

Teknik pengumpulan data yang digunakan dalam penelitian ini adalah kuesioner dan pedoman wawancara. Kuesioner digunakan untuk menjaring data pada responden kepala madrasah, guru, peserta didik, pengawas dan komite madrasah. Sedangkan wawancara diarahkan kepada pejabat Kemenag (Pusat dan Daerah), kepala madrasah, pengawas, dan komite yang memiliki kewenangan mengambil kebijakan. Mereka yang diwawancarai adalah mereka yang dapat dipertimbangkan memenuhi syarat untuk memberikan pandangan, dan penilaian terhadap pengembangan Kurikulum 2013 dan mampu memberikan jawaban atas pelaksanaan kegiatan dan perkembangannya serta pengaruhnya terhadap warga madrasah.

Populasi dalam penelitian ini adalah seluruh kepala MA, guru PAI, kepala TU, pengawas, dan Komite madrasah yang berada pada 8 MA piloting implementasi Kurikulum 2013. Sampel dalam penelitian ini adalah : Kepala Madrasah (8 orang), Guru Pendidikan Agama Islam (30 orang), Peserta didik (30 orang), Kepala TU (8 orang), Komite Madrasah (8 orang), dan Pengawas Madrasah (2 orang). Responden kepala MA, kepala TU, dan Ketua Komite Madrasah diambil seluruh populasi yaitu 8 MA di kota Depok. Sedangkan responden pengawas diambil dari pengawas yang bertugas pada $8 \mathrm{MA}$ tersebut. Untuk responden guru Pendidikan Agama Islam (PAI) dan peserta didik diambil secara acak.
Secara umum perlaksanaan penelitian ini menggunakan teknik analisis deskriptif. Analisis deskriptif digunakan untuk menjelaskan secara utuh implementasi kurikulum 2013 yang didasarkan kepada kriteria-kriteria/indikator tertentu. Pengukuran sejauhmana tujuan pelaksanaan program/kegiatan tercapai digunakan sebagai bahan pertimbangan dalam mengambil suatu kebijakan atau keputusan.

\section{HASIL DAN PEMBAHASAN}

\section{Kebijakan dan Mekanisme Penetapan Madrasah}

Implementasi Kurikulum 2013 di madrasah dilakukan melalui beberapa proses atau tahapan-tahapan. Pertama, dari segi kebijakan. Kebijakan implementasi kurikulum 2013 di wilayah propinsi Jawa Barat berangkat dari : (1) Surat Edaran Dirjen Pendis nomor SE/Dj.I/PP.00/50/2013 tanggal 8 Juli 2013 tentang Implementasi Kurikulum 2013 pada madrasah disebutkan bahwa 1) Kemenag RI akan melaksanakan Kurikulum 2013 untuk MI, MTs dan MA mulai TP. 2014/2015 pada kelas I dan IV, kelas VII dan kelas X, dan 2) pada TP. 2013/2014 Kemenag akan melakukan persiapan implementasi Kurikulum 2013 dalam bentuk pelatihan Kamad, Pengawas Madarsah dan Pendidik serta pengadaan bahan ajar dan buku pedoman guru. (2) Surat Edaran Dirjen Pendis nomor SE/ Dj.I/HM.01/114/2014 tanggal 6 Juli 2014 disebutkan bahwa Direktorat Pendidikan Madrasah Dirjen Pendis akan melaksanakan Kurikulum 2013 mulai TP. 2014/2015 sesuai jenjang untuk Kelas I dan IV (MI), kelas VII (MTs) dan kelas X (MA) dan pentahapan implementasinya akan selesai pada TP. 
2016/2017; (3) Keputusan Dirjen Pendis Nomor 2676 tahun 2013 tanggal 1 Oktober 2013 tentang Kurikulum 2013 Mapel PAI dan Bahasa Arab di Madrasah disebutkan antara lain Kurikulum MI, MTs dan MA dilaksanakan berdasarkan Kurikulum 2013 yang berlaku secara nasional dan Kurikulum 2013 Mapel PAI dan Bahasa Arab di Madrasah mencakup kerangka dasar dan struktur kurikulum, standar isi, standar psoses dan standar penilaian PAI dan bahasa Arab. (4) Keputusan Menteri Agama Nomor 165 Tahun 2014 tentang Pedoman Kurikulum Madrasah 2013 Mata Pelajaran Pendidikan Agama Islam dan Bahasa Arab; (5) KMA Nomor 117 tahun 2014 tanggal 14 Juli 2014 tentang Implementasi Kurikulum 2013 di Madrasah.

Kedua, dari segi proses penetapan madrasah.Penetapanmadrasahyangmenjadi sasaran dalam mengimplementasikan kurikulum 2013 didasarkan pada (1) Hasil rakor dengan subdit kurikulum direktorat pendidikan madrasah, sosialisasi dan bimtek kurikulum 2013 dan pendampingan kurikulum 2013 baik yang dilakukan oleh pusat, provinsi maupun kab./kota; (2) Keputusan Dirjen Pendis Nomor 481 Tahun 2015 tanggal 26 Januari 2015 tentang Penetapan Madrasah Pendampingan Implementasi Kurikulum 2013 pada Madrasah Yang Lanjut Kurikulum 2013, yang difokuskan hanya untuk madrasah di Kota Depok; (3) Pada TP. 2015/2016, Kemenag mendata seluruh Madrasah Negeri untuk ditetapkan sebagai madrasah yang kembali mengimplementasikan Kurikulum 2013 pada kelas I dan IV (MI), kelas VII (MTs) dan kelas X (MA), sedangkan madrasah swasta yang siap diusulkan untuk ditetapkan, selanjutnya pada tahun yang sama
Kanwil kemenag Provinsi mengusulkan seluruh Marasah Negeri dan Swasta untuk ditetapkan sebagai madrasah yang kembali mengimplementasikan kurikulum 2013 TP. 2015/2016 ke Dirjen Pendis sesuai Keputusan Dirjen Pendis Nomor 5114 Tahun 2016 tanggal 7 September 2015 tentang Penetapan Madrasah pelaksana Kurikulum 2013 TP. 2015/2016; (4) Pada TP. 2016/2017, seluruh Madrasah untuk ditetapkan sebagai madrasah yang kembali mengimplementasikan Kurikulum 2013 secara utuh pada kelas I, II, IV dan V (MI), kelas VII dan VII (MTs) dan kelas X dan XI (MA), Keputusan Dirjen Pendis Nomor 5114 Tahun 2016 Tgl. 7 September 2015 dan SK Dirjen Pendis Nomor 3932 tahun 2016 tentang Penetapan Madrasah pelaksana Kurikulum 2014 TP. 2016/2017, sementara untuk kelas III dan VI, kelas IX dan XII mengimplementasikan Kurikulum 2013 untuk mael PAI dan Bahasa Arab dan KTSP 2006 untuk mapel umum.

Dalam perumusan kebijakan penetapan madrasah untuk mengimplementasikan kurikulum 2013 melibatkan berbagai pihak. Ditingkat pusat kebijakan penetapan madrasah untuk mengimplementasikan kurikulum 2013 ditetapkan oleh Menag RI melalui Dirjen Pendis dan Direktur Madrasah melalui subdit kurikulum dan evaluasi. Di tingkat provinsi kebijakan ditetapkan oleh Kepala Kanwil Kemenag provinsi melalui Kabid Madrasah. Sedangkan di tingkat Kab./ Kota oleh Kepala Kantor Kemenag Kab./Kota melalui Kasi Penmad/Pendis dan Pengawas Pendidikan Madrasah dan di tingkat satuan pendidikan oleh Kepala Madrasah, guru dan tenaga kependidikan. Proses penetapan madrasah ini memang down-up, artinya usulan nama-nama madrasah yang 
akan memberlakukan kurikulum 2013 itu dari bawah (satuan pendidikan). Setelah menerima SK terkait dengan penerapan kurikulum 2013 dari Kemenag pusat, kanwil Propinsi Jawa Barat melakukan verifikasi terhadap madrasah-madrasah yang akan menjadi pilot project kurikulum 2013.

Verifikasi madrasah selanjutnya diserahkan ke Kemenag Kab/Kota Depok. Di propinsi Jawa Barat wilayah Depok dipilih untuk menjadi pilot project implementasi kurikulum 2013. Kemenag Kota Depok melalui MKKM (Musyawarah Kerja Kelompok Madrasah) mengusulkan nama-nama madrasah yang sudah siap untuk mengimplementasikan kurikulum 2013 ke kemenag Kota Depok. Selanjutnya Kemenag Kota Depok memberikan data hasil verifikasi madrasah ke Kabid Pendidikan Madrasah Kanwil melalui Kasubdit Kurikulum Kemenang Propinsi. Kemudian terbit surat Keputusan Dirjen Pendis Nomor 481 Tahun 2015 tanggal 26 Januari 2015 tentang Penetapan Madrasah Pendampingan Implementasi Kurikulum 2013 pada Madrasah Yang Lanjut Kurikulum 2013, yang difokuskan hanya untuk madrasah di Kota Depok dengan menunjuk 8 Madrasah Aliyah (MA) sebagai piloting dalam implementasi kurikulum 2013. Namanama Madrasah Aliyah tersebut adalah : MA Arrido, MA Islamiyah, MA Darussalam, MA Qutrotunnada, MA Nur Al Zahra, MA YPPD, MAArrahmaniyah, dan MA Nurul Huda Assuriyah.

\section{Implementasi Kurikulum di Madrasah}

Implementasi kurikulum 2013 mencakup dua hal yaitu pemahaman terhadap kurikulum 2013 dan bagaimana implementasinya. Pemahaman kurikulum 2013 ini dilihat dari pemahaman terkait tujuan kurikulum 2013 dan pendekatan saintifik. Hasil penelitian ini menunjukkan bahwasebanyak 75\%guruPAI, $50 \%$ pengawas, dan $76.70 \%$ peserta didik memahami tujuan dari diimplementasikan kurikulum 2013, bahkan seluruh kepala madrasah sasaran penelitian ini sudah memahami tujuan dari implementasi kurikulum 2013. Untuk pemahaman pendekatan saintifik yang digunakan dalam kurikulum 2013, sebanyak 75\% kepala MA, $87.5 \%$ guru PAI dan $50 \%$ pengawas juga menyatakan sudah memahami pendekatan saintifik dalam kurikulum 2013 dimana peserta didik dituntut untuk melakukan pengamatan, mengajukan pertanyaan, melakukan praktek menalar serta mempresentasikan hasil yang sudah dikerjakannya. Sedangkan implementasi kurikulum 2013 dilihat dari perencanaan dan proses pembelajaran. Dalam perencanaan kurikulum 2013, guru wajib menyusun Rencana Pelaksanaan Pembelajaran (RPP) dan juga memahami komponen-komponen RPP sesuai kurikulum 2013. Data hasil penelitian ini menunjukkan bahwa sebanyak $96.88 \%$ guru PAI yakin mereka mampu menyusun RPP. Hal ini dikuatkan oleh pendapat seluruh Kepala MA bahwa guru-guru mampu menyusun RPP sesuai Kurikulum 2013. Namun demikian baru 75\% guru PAI yang sudah memahami komponen-komponen sesuai Kurikulum 2013. Hal ini didukung dengan pendapat kepala MA (75\%) yang menyatakan bahwa guru PAI yang sudah memahami komponenkomponen sesuai Kurikulum 2013.

Terkait dengan proses pembelajaran dengan kurikulum 2013, baik kepala MA, guru madrasah (PAI), maupun peserta 
didik menyatakan bahwa para guru sudah cukup mampu melaksanakan proses pembelajaran dengan kurikulum 2013. Hasil penelitian menunjukkan bahwa sebanyak 68.84\% Kepala MA dan $84.14 \%$ guru PAI menyatakan yakin bahwa para guru PAI sudah memiliki kemampuan dalam pembelajaran dengan kurikulum 2013 yang dilihat dari 10 aspek yaitu : (1) mampu untuk melakukan proses pembelajaran dengan menggunakan pendekatan tematik. (2) mampu melaksanakan proses pembelajaran dengan pendekatan saintifik. (3) guru mampu melaksanakan proses pembelajaran yang menuju keterampilan aplikatif. (4) mampu untuk melakukan proses pembelajaran yang membuat peserta didik menjadi lebih sering bertanya. (5) mampu untuk melaksanakan proses pembelajaran yang membuat peserta didik menjadi lebih berani mengemukakan pendapat. (6) mampu melakukan proses pembelajaran yang membuat peserta didik menjadi ingin melakukan observasi. (7) mampu untuk melakukan proses pembelajaran yang membuat peserta didik menjadi ingin melakukan eksperimen. (8) mampu untuk melakukan proses pembelajaran yang menumbuhkan kreatifitas peserta didik. (9) mampu untuk memanfaatkan IT (teknologi informasi) yang tersedia di madrasahnya dalam proses pembelajaran. (10) guru mampu untuk memulai dan mengakhiri proses pembelajaran sesuai dengan waktu yang dijadwalkan.

Menurut para kepala MA tersebut, kesepuluh aspek diatas sudah cukup baik namun ada 2 aspek yang dinilai masih agak rendah yaitu aspek kemampuan guru untuk mendorong siswa melakukan eksperimen (50\%) dan aspek memanfaatkan teknologi informasi (58\%). Sedangkan menurut guru PAI, dari sepuluh aspek diatas, ada 2 aspek yang paling rendah yaitu kemampuan guru untuk melakukan proses pembelajaran yang membuat peserta didik menjadi ingin melakukan eksperimen (62.51\%) dan kemampuan guru melaksanakan proses pembelajaran dengan pendekatan saintifik (71.88\%). Sementara itu, sebanyak 65,17\% peserta didik menilai bahwa kemampuan guru dalam proses pembelajaran dengan kurikulum 2013 juga sudah cukup baik. Namun dari 10 aspek yang dinilai, ada 3 aspek kompetensi guru yang masih rendah yaitu kemampuan guru dalam menggunakan teknologi informasi (13,33\%), kemampuan guru dalam melatih peserta didik untuk melakukan pengamatan (20\%), dan kemampuan guru dalam melatih untuk melakukan percobaan (36,6\%).

Selain penilaian peserta didik terkait dengan kurikulum 2013, para peserta didik juga memberikan penilaian terkait dengan implementasi kurikulum 2013. Mereka menyayangkanjika implementasi kurikulum ini tidak di dukung dengan berbagai fasilitas dan sarana prasarana pembelajaran yang memadai. Dalam implementasi kurikulum peserta didik dituntut untuk mandiri. Ini perlu didukung dengan berbagai fasilitas penunjang pembelajaran seperti buku-buku referensi, buku-buku penunjang, internet untuk siswa, dan lain sebagainya.

\section{Dampak Penerapan Kurikulum 2013}

Implementasi Kurikulum 2013 memiliki dampak tidak hanya bagi peserta didik namun juga pada guru dan Kepala MA. Hasil penelitian dibawah ini menunjukkan 
dampak implementasi Kurikulum 2013 terhadap ketiga warga madrasah tersebut.

Dampak Kurikulum 2013 pada Peserta Didik. Secara keseluruhan, sebanyak 89.96\% responden yakin bahwa Kurikulum 2013 berdampak positif pada peserta didik yang dilihat dari 8 aspek, yaitu : (1) Proses pembelajaran menjadi lebih menarik dan menyenangkan; (2) peserta didik menjadi lebih aktif bertanya dan mengemukakan pendapat; (3) termotivasi untuk melakukan observasi; (4) peserta didik memiliki semangat belajar yang lebih tinggi (5) menjadi lebih terampil, inovatif dan produktif; (6) peserta didik memiliki daya nalar yang lebih baik; (7) peserta didik memiliki hasrat yang lebih tinggi untuk membaca dan (8) Karakter peserta didik lebih terbangun (lebih sopan, jujur, menghormati perbedaan dll). Dari 8 aspek tersebut, ada 2 aspek yang sangat diyakini oleh kepala madrasah bahwa kurikulum 2013 dapat membuat daya nalar peserta didik akan lebih baik dan karakter peserta didik dapat lebih terbangun (lebih sopan, jujur, menghormati perbedaan dll).

Sementara itu menurut guru PAI, ada 2 aspek yang diyakini bahwa kurikulum 2013 memiliki dampak positif pada peserta didik yaitu peserta didik menjadi lebih aktif bertanya dan mengemukakan pendapat (84.38\%) dan karakter peserta didik dapat lebih terbangun (lebih sopan, jujur, menghormati perbedaan dll) (87,5\%). Sedangkan menurut pengawas, dari 8 aspek diatas ada 3 aspek yang sangat diyakini akan berdampak positif pada peserta didik yaitu peserta didik lebih termotivasi untuk melakukan observasi, peserta didik memiliki semangat belajar yang lebih tinggi dan karakter peserta didik dapat lebih terbangun (lebih sopan, jujur, menghormati perbedaan dll). Begitu juga dengan pendapat komite madrasah. Dari 7 aspek yang dinilai, ada 4 aspek yang sangat diyakini oleh komite akan dampak positif kurikulum 2013 terhadap peserta didik yaitu pada aspek : (1) peserta didik menjadi lebih aktif bertanya dan mengemukakan pendapat; (2) peserta didik memiliki semangat belajar yang lebih tinggi, menjadi lebih terampil, inovatif dan produktif; (3) peserta didik memiliki daya nalar yang lebih baik; dan (4) Karakter peserta didik lebih terbangun (lebih sopan, jujur, menghormati perbedaan dll).

Dampak Kurikulum 2013 pada Guru. Ada 3 (tiga) responden yang menilai dampak kurikulum 2013 pada guru yaitu kepala madrasah, guru, dan pengawas. Secara keseluruhan, sebanyak $77,78 \%$ responden yakin bahwa Kurikulum 2013 berdampak positif pada guru yang dilihat dari 9 aspek yaitu : (1) Guru akan lebih bersemangat untuk meningkatkan kualitas pembelajaran, (2) Guru akan lebih bersemangat untuk menambah pengetahuan, (3) Guru akan lebih bersemangat mengembangkan metode pembelajaran, (4) Guru akan lebih bersemangat untuk memperkaya bahan ajar, (5) Guru akan lebih memperhatikan murid satu persatu, (6) Guru akan lebih obyektif dalam menilai kemampuan murid, (7) Guru akan memiliki kemampuan untuk mengintegrasikan pembelajaran dengan pendekatan ilmiah dan membangun karakter peserta didik, (8) Guru merasa lebih mudah dalam menyusun RPP, dan (9) Waktu yang dibutuhkan untuk menyusun RPP menjadi lebih singkat.

Dari sembilan aspek tersebut, ada 2 aspek yang sangat diyakini oleh seluruh kepala MA yaitu implementasi kurikulum 
2013 akan berdampak pada guru yaitu guru akan lebih bersemangat mengembangkan metode pembelajaran dan juga lebih bersemangat untuk memperkaya bahan ajar. Demikian juga dengan pendapat guru itu sendiri. Mereka meyakini bahwa implementasi kurikulum akan menjadikan guru lebih bersemangat mengembangkan metode pembelajaran (93.76\%). Sedangkan menurut pengawas, ada 5 aspek yang sangat diyakini terkait dampak implementasi kurikulum 2013 terhadap guru yaitu : (1) guru akan lebih bersemangat untuk memperkaya bahan ajar, (2) guru akan lebih obyektif dalam menilai kemampuan murid, (3) guru akan memiliki kemampuan untuk mengintegrasikan pembelajaran dengan pendekatan ilmiah dan membangun karakter murid, (4) guru merasa lebih mudah dalam menyusun RPP, dan (5) waktu yang dibutuhkan untuk menyusun RPP menjadi lebih singkat.

\section{Dampak Kurikulum 2013 Pada Kepala}

MA. Secara keseluruhan, sebanyak 86,25\% responden yakin bahwa Kurikulum 2013 berdampak positif pada Kepala MA yang dilihat dari 5 aspek yaitu : (1) Lebih aktif melakukan supervisi terhadap proses pembelajaran di kelas, (2) Lebih aktif mendorong guru untuk konsisten menerapkan hal yang diperoleh di pelatihan dengan pelaksanaan di kelas, (3) Lebih termotivasi menjadi teman belajar para guru, (4) Lebih termotivasi mengadakan pelatihan mandiri untuk pengembangan kompetensi guru, dan (5) Lebih termotivasi mengembangkan manajemen sekolah. Dari 5 aspek tersebut ada dua aspek yang paling menonjol yaitu : (1) Kepala MA lebih aktif melakukan supervisi terhadap proses pembelajaran di kelas dan dan (2 Kepala
MA lebih termotivasi mengembangkan manajemen sekolah. Menurut kepala madrasah, seluruh aspek tersebut diyakini memberikan dampak yang positif pada kepalamadrasah,terutamadalammelakukan supervisi yang lebih aktif terhadap proses pembelajaran di kelas dan juga termotivasi mengembangkan manajemen sekolah. Sedangkan menurut pengawas, dari 5 aspek tersebut, ada 3 aspek yang berdampak positif pada kepala madrasah yaitu aspek supervisi yang lebih aktif terhadap proses pembelajaran di kelas, lebih termotivasi menjadi teman belajar para guru, dan lebih termotivasi mengembangkan manajemen sekolah.

\section{Faktor Pendukung dan Kendala}

Banyak faktor yang mendukung dalam implementasi kurikulum di Madrasah Aliyah (MA) seperti : Pertama, buku teks pelajaran. Buku teks pelajaran merupakan salah satu sarana yang menunjang pelaksanaan kurikulum 2013. Sebanyak 80\% responden menyatakan bahwa Buku Teks Pelajaran di MA sudah cukup baik. Hal ini dilihat dari 5 aspek penilaian yaitu : isi mencakup ranah kompetensi sikap, pengetahuan dan ketrampilan sesuai K-13; Contoh-contoh kegiatan dalam buku tersebut mudah dilakukan oleh peserta didik; ilustrasi dalam buku cukup bagus; Bahasa dalam buku mudah dipahami; dan buku tersebut efektif dalam meningkatkan efektivitas proses pembelajaran. Kedua, buku pegangan guru. Sebanyak $80 \%$ responden juga menilai bahwa buku Pegangan Guru untuk Kurikulum 2013 cukup baik. Hal ini dilihat dari 5 aspek penilaian yaitu: membantu guru dalam merencanakan proses pembelajaran; 
memberikan panduan yang jelas tentang penerapan pembelajaran tematik berbasis mata pelajaran; memberikan panduan yang jelas tentang penerapan pembelajaran saintifik; memberikan panduan yang jelas tentang penerapan penilaian otentik; membantu meningkatkan efektivitas proses pembelajaran di kelas. Ketiga, sarana prasarana. Sarana prasarana sangat dibutuhkan dalam menunjang pembelajaran dengan kurikulum 2013. Menurut pengawas, ketersediaan buku-buku pelatihan di Madrasah Aliyah (MA) tidak ada. Alat peraga sebagian tersedia namun banyak yang tidak relevan untuk pembelajaran dengan kurikulum 2013.

Keempat, Pelatihan Kurikulum 2013, masalah pelatihan kurikulum 2013 mencakup beberapa hal seperti : (1) Materi Pelatihan. Sebanyak $77.27 \%$ responden menilai bahwa materi cukup baik. Hal ini dilihat dari 11 aspek. Dari aspek-aspek tersebut, ada 6 aspek yang lebih dominan yaitu : (1) materi pelatihan cukup sesuai dengan kebutuhan pembelajaran dalam Kurikulum 2013; (2) materi pelatihan relevan dalam mengubah pola pikir; (3) materi pelatihan memuat hal-hal baru dalam pembelajaran (proses perencanaan, pelaksanaan, penilaian dan pengawasan); (4) konsep penilaian otentik tersampaikan dengan baik dalam pelatihan; (5) petunjuk pembuatan RPP telah tersampaikan dengan baik; dan (6) Setelah mengikuti pelatihan peserta memperoleh gambaran yang jelas terhadap proses pembelajaran yang sesuai dengan Kurikulum 2013. (2) Metode dan Alokasi Waktu Pelatihan. Sebanyak 87.5\% responden menilai bahwa metode dan alokasi waktu dalam pelatihan kurikulum 2013 cukup baik. Hal ini bisa dilihat dari
4 aspek yaitu : metode pelatihan cukup mudah; metode pelatihan sesuai dengan tujuan Kurikulum 2013; metode pelatihan menyenangkan; dan waktu yang disediaan dalam pelatihan cukup memadai. (3). Pelatih/Instruktur. Penilaian terhadap pelatih/instruktur diukur dari penguasaan materi oleh pelatih dan cara penyampaian materi. Seluruh responden menilai bahwa pelatih/instruktur kurikulum 2013 cukup menguasai materi pelatihan dan cara penyampaian materi pelatihan juga agak mudah diterima.

Beberapa masalah atau kendala yang diutarakan baik Kepala Madrasah, Guru, Pengawas, Komite maupun peserta didik terkait implementasi Kurikulum 2013 antara lain : (1) Kurangnya sarana prasarana penunjang pembelajaran, (2) Kurangnya pelatihan Kurikulum 2013 bagi guru, (3) Minimnya buku pegangan guru dan buku untuk siswa, (4) Rumitnya model penilaian siswa bagi guru, (5) Tidak ada evaluasi dan monitoring dari pemerintah terhadap implemntasi Kurikulum 2013.

\section{PENUTUP}

Implementasi Kurikulum 2013 di 8 (delapan) MA swasta pilot project implementasi kurikulum 2013 di kantor wilayah Kementerian Agama propinsi Jawa Barat cukup berhasil. Sebagian besar guru PAI, pengawas madrasah, dan peserta didik memahami tujuan dari diimplementasikan kurikulum 2013, bahkan seluruh kepala madrasah sasaran penelitian ini sudah memahami tujuan dari implementasi kurikulum 2013. Selain itu sebagian besar kepala MA, guru dan pengawas juga sudah memahami pendekatan saintifik 
dimana peserta didik dituntut untuk melakukan pengamatan, mengajukan pertanyaan, melakukan praktek menalar serta mempresentasikan hasil yang sudah dikerjakannya. Dalam pelaksanaan pembelajaran dengan Kurikulum 2013, baik kepala MA maupun guru PAI menyatakan bahwa para guru sudah cukup mampu melaksanakan proses pembelajaran dengan kurikulum 2013.

Implementasi Kurikulum 2013 juga memiliki dampak positif baik bagi peserta didik, guru, dan juga Kepala MA. Hal ini didukung oleh berbagai faktor seperti kualitas buku teks pelajaran dan buku pegangan guru serta sarana prasarana penunjang lainnya. Faktor penunjang keberhasilan implementasi kurikulum 2013 adalah kualitas pelatihan kurikulum 2013 seperti kualitas materi pelatihan, metode alokasi pelatihan, dan profesionalisme pelatih/instruktur. Namun demikian masih ada beberapa permasalahan yang muncul antara lain : (1) Kurangnya sarana prasarana penunjang pembelajaran, (2) Kurangnya pelatihan Kurikulum 2013 bagi guru, (3) Minimnya buku pegangan guru dan buku untuk siswa, (4) Rumitnya model penilaian siswa bagi guru, dan (5) Tidak ada evaluasi dan monitoring dari pemerintah terhadap implementasi Kurikulum 2013.

Dari kesimpulan di atas, studi ini merekomendasikan: Pertama, perlu kegiatan bimtek kurikulum 2013 secara intensif untuk semua guru mata pelajaran. Kedua, perlu pemenuhan kebutuhan buku pegangan guru dan buku pelajaran bagi peserta didik. Ketiga, perlu pemenuhan sarana prasarana penunjang kurikulum 2013 seperti internet, buku-buku referensi, laboratorium, dan sebagainya. Keempat, model penilaian untuk peserta didik perlu disederhanakan. Kelima, ada program evaluasi dan monitoring bagi Madrasah Aliyah (MA) yang sudah menerapkan Kurikulum 2013 sehingga perkembangannya terpantau.

\section{UCAPAN TERIMA KASIH}

Terima kasih kepada Kepala Puslitbang Pendidikan Agama dan Keagamaan Badan Litbang dan Diklat yang telah memberi kesempatan kepada penulis untuk meneliti, Kabid Pendidikan Madrasah Kanwil Kementerian Agama Jawa Barat, Kasi Pendidikan Madrasah Kota Depok, para kepala dan wakil Kepala Madrasah Aliyah di Kota Depok, guru-guru PAI, kepala Tata Usaha MA Aliyah di Kota Depok, dan para pesera didik MA di Kota Depok yang turut membantu memberikan data dan informasi, juga kepada Redaktur Edukasi atas termuatnya tulisan ini. Semoga tulisan ini memberikan wawasan dalam pendidikan agama di Indonesia.

\section{DAFTAR PUSTAKA}

Arikunto, Suharsimi (2004) : Dasar-Dasar Evaluasi Pendidikan. Jakarta, Bumi Aksara

Basri, Hasan dan Beni Ahmad Saebani (2010): Ilmu Pendidikan Jilis II. Bandung, CV Pustaka Setia, Cet ke-1

Djaali dan Puji (2008): Pengukuran Dalam Bidang Pendidikan. Jakarta, Grasindo

Hamriah (2014): Implementasi Kurikulum 2013 pada Madrasah Tsanawiyah Negeri (MTsN) Model Makasar, Al Qalam, $20: 55$ $-62$

Harsono, Hanifah (2002): Implementasi Kebijakan dan Politik. Bandung, PT. Mutiara Sumber Widya 
Hasan (1999): Landasan Filosofi dan Teori Penyusunan Kurikulum, makalah disajikan dalam Seminar Kinerja PPPG-IPA. Bandung, 28 Juni 1999.

Klein, M.F. (1989): Curriculum Reform in the Elementary Schoo l: Creating your own agenda. New York and London, Teacher College Columbia University

Miller, J.P. and Seller, W (1985): Curriculum Perspektif and Practice. New York, Longman

Mulyasa (2008): Implementasi Kurikulum Tingkat Satuan Pendidikan, Kemandirian Guru dan Kepala Sekolah. Jakarta, Bumi Aksara

Munawir, A. Warson (1997): Kamus AlMunawir. Surabaya, Pustaka Progresif, Cet XIV

Muzamiroh, M.L. (2013): Kupas Tuntas Kurikulum 2013. Jakarta, Penata aksara

Noviatmi, Andri (2015). Evaluasi Implementasi Kurikulum 2013 Kelas I \& IV SD di Kabupaten Magelang Tahun Pelajaran 2014/2015. Thesis. Prodi Pendidikan Dasar, Program Pascasarjana, Universitas Negeri Yogyakarta
Oliva P.F. (1997): Developing the Curriculum 4th edition. New York, Longman

Peraturan Pemerintah Nomor 19 Tahun 2005 tentang Standar Nasional Pendidikan

Setiawan, Guntur (2004): Implementasi Dalam Birokrasi Pembangunan. Bandung, Remaja Rosdakarya Offset

Siskandar (2016): Evaluasi Implementasi Kurikulum di Madrasah Aliyah. Cendikia, 10 (2) : 117 - 132

Sukmadinata, N.S. (2011): Metode Penelitian Pendidikan. Bandung, PT Remaja Rosdakarya, Cet ke-7

Taruna, Mulyani Mudis (2015): Kontribusi Madrasah Dalam Penguatan Kurikulum 2013 (Studi tentang Kesiapan Madrasah Dalam Pelaksanaan Kurikulum 2013 di Jawa Tengah, Analisa Journal of Social Science and Religion, 22 (01) : 107-119

Undang-Undang Nomor 20 Tahun 2003 Tentang Sistem Pendidikan Nasional Pasal 57 ayat (2)

Usman, Nurdin (2002): Konteks Implementasi Berbasis Kurikulum. Jakarta, PT Raja Grafindo Peserta 